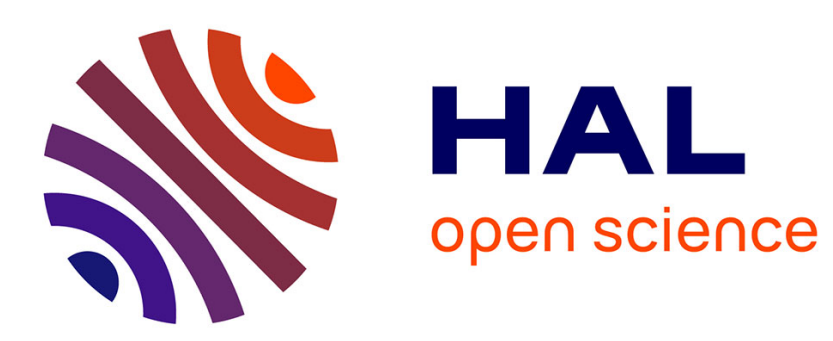

\title{
Proposal for a poverty-adaptation-mitigation window within the Green Climate Fund
}

\author{
Sandrine Mathy, Odile Blanchard
}

\section{To cite this version:}

Sandrine Mathy, Odile Blanchard. Proposal for a poverty-adaptation-mitigation window within the Green Climate Fund. Climate Policy, 2016, 16 (6), pp.752-767. 10.1080/14693062.2015.1050348 . hal-01149008

\section{HAL Id: hal-01149008 \\ https://hal.univ-grenoble-alpes.fr/hal-01149008}

Submitted on 6 May 2015

HAL is a multi-disciplinary open access archive for the deposit and dissemination of scientific research documents, whether they are published or not. The documents may come from teaching and research institutions in France or abroad, or from public or private research centers.
L'archive ouverte pluridisciplinaire HAL, est destinée au dépôt et à la diffusion de documents scientifiques de niveau recherche, publiés ou non, émanant des établissements d'enseignement et de recherche français ou étrangers, des laboratoires publics ou privés.

\section{다(1)(2)}

Distributed under a Creative Commons Attribution - ShareAlikel 4.0 International 


\title{
Proposal for the creation of a poverty- adaptation-mitigation funding window within the Green Climate Fund
}

\author{
Sandrine Mathy ${ }^{1,2}$, Odile Blanchard ${ }^{1,2}$ \\ ${ }^{1}$ Univ.Grenoble Alpes, PACTE, EDDEN, BP 47, F-38040 Grenoble, France, \\ ${ }^{2}$ CNRS, PACTE, EDDEN, BP 47, F-38040 Grenoble, France
}

Corresponding author : sandrine.mathy@upmf-grenoble.fr ; +33456528595

April 2015

\section{Key Words}

International climate change negotiations, Green Climate Fund, poverty, mitigation, adaptation, basic needs

\section{Abstract}

The stakes for alleviating poverty and avoiding unbridled climate change are inextricably linked. Climate change impacts will slow down and may even reverse trends in poverty reduction. The pathways consistent with global warming of no more than $2^{\circ} \mathrm{C}$ require strategies for poverty alleviation to make allowance for the constraint of low-carbon development. Existing climate funds have failed to target poverty alleviation as a highpriority strategy for adaptation or as a component of low-carbon development. This article proposes a funding window as part of the Green Climate Fund in order to foster synergies targeting greater satisfaction of basic needs, while making allowance for adaptation and mitigation. This financial mechanism is based on indicators of the satisfaction of basic needs and could respond to the claims of the developing countries which see alleviating poverty as the first priority in the climate negotiations. It defines a country continuum, given that there are poor people everywhere; all developing countries are therefore eligible with a mechanism of this sort. 


\section{Policy relevance statement}

The IPCC calls for substantial emissions reductions and adaptation strategies over the next decades to reduce the high risks of severe impacts of climate change over the $21^{\text {st }}$ century. Industrialized countries and developing countries alike recognize the need to mitigate climate change and to adapt to it. But they face many challenges that lead to an "emissions gap" between an emissions level consistent with the $2^{\circ} \mathrm{C}$ increase limit and the voluntary pledges that they have made thus far in the climate negotiations (UNEP, 2014). In this arena, many developing countries underline that their first domestic priority is the satisfaction of basic needs. In the run-up to the next climate negotiations at COP 21 in Paris, the proposed Poverty-Adaptation-Mitigation-funding window could contribute to alleviate the conflict between development and climate goals in developing countries. In this sense, it could spur developing countries to integrate more ambitious emissions limitations pledges into their Intended Nationally Determined Contributions. This could in turn entice industrialized countries to act similarly. In the end, it could pave the way to an ambitious climate agreement in Paris at COP21. 


\section{Introduction}

The year 2015 will see two major international events: negotiations to set new Sustainable Development Goals (SDGs) with the reaffirmed goal of ending extreme poverty, and the 21st International Conference on Climate Change (COP21). The coincidence of these two events recalls how poverty and climate change, two major challenges for the coming decades, are intertwined.

Despite substantial progress in reducing extreme poverty rates in developing regions over the last 20 years, from $47 \%$ of the population in 1990 to $22 \%$ in 2014, 1.2 billion people still live with less than $\$ 1.25$ a day : 400 million in India, 400 million in sub-Saharan Africa, 150 million in China (UNDP, 2014; UNECA et al., 2014). Poverty goes hand-in-hand with largescale failures to satisfy several basic needs: 840 million people in the world suffer from hunger; 2.5 billion lack access to improved sanitation facilities; 863 million urban residents live in slums (UN-Habitat, 2013); worldwide, 2.7 billion people use biomass to cook their food, with devastating effects on their health (IEA, 2011); in sub-Saharan Africa, only $32 \%$ of the population has access to electricity (59\% in towns and only $16 \%$ in rural areas); in India the figure is $75 \%$ (IEA, 2014).

Climate change is very likely to be a major hurdle to the eradication of poverty (Skoufias et al., 2011; Shepherd et al., 2013). Climate change will not only worsen the situation of the poor; it will also very likely reverse the trend of decreasing poverty (Hallegatte et al., 2014). Therefore, to limit overall climate change impacts and particularly on the poorest populations, global warming has to be limited to $2^{\circ} \mathrm{C}$ at most. This means, according to IPCC (IPCC, 2014), that the world's population must become carbon neutral by the end of the $21^{\text {st }}$ century. Development strategies including poverty eradication will thus need to integrate mitigation strategies. However poverty alleviation usually induces an enlargement of basic needs which may lead to a very high growth in energy services and consumption: for example when people get access to modern energy, their energy consumption tends to rise rapidly above the very low, initial level (Wolfram et al., 2012; Gertler et al., 2011). It is thus important that pro-poor policies are designed in such a way as to be consistent with climate mitigation, which is possible according to Hallegatte et al. (2014). 
In spite of these inextricable links between climate change and poverty, until the early 2000s international forums generally addressed the two challenges separately. Policies and strategies to achieve the Millennium Development Goals focused mainly on 'developmentfirst' actions (UN, 2005); international climate negotiations dealt with 'climate (mitigation) first' issues, even if many developing countries repeatedly pointed that other more urgent issues, including poverty eradication were on their agendas (Kasa et al, 2008 ; Rajamani, 2007) $)^{1}$.

The intertwined issues of development and climate change gained considerable momentum by the mid-2000s. Following Beg et al. (2002), and Winkler et al. (2002), Bradley et al. (2005) further investigated Sustainable Development-Policies and measures (SD-PAMs), putting domestic development policies first while having a positive effect on GHG emissions. Similarly, Halsnæs and Garg (2006) suggested to build climate policies around development priorities and considered the potential contribution to mitigation by developing countries as a side-benefit of sustainable development.

The fourth IPCC assessment report reviewed the literature on the two-way nature of the relationship between climate change (mitigation) and sustainable development' (IPCC, 2007b, p. 695): actions limiting GHG emissions may generate development co-benefits, while well-tailored sustainable development strategies may contribute to climate mitigation.

A triangular relationship has even formed between climate change and sustainable development since the mid-2000s, with climate-change negotiations increasingly addressing concerns about adaptation as well as mitigation. The fourth IPCC assessment report emphasized the inter-relationship between climate adaptation and mitigation (IPCC, 2007a). Clapp et al. (2010) suggested low-emissions development strategies (LEDS) which integrate mitigation and/or climate-resilient policies. These LEDS were incorporated in the 2009 Copenhagen Accord and the 2010 Cancun Agreements (UNFCCC, 2009, 2010). Since COP 19 in Warsaw the scope of international negotiation has evolved in such a way that the Parties at COP 21 will negotiate on the basis of Intended Nationally Determined Contributions (UNFCCC, 2013). In this context national research teams of the Deep Decarbonization

\footnotetext{
${ }^{1}$ It is worth noting that, among the G77+China Group, the Small Island Developing States and the Least Developed Countries did not and still do not share this position as they are the countries most exposed to climate-change impacts: they strongly advocate a $1.5^{\circ} \mathrm{C}$ maximum temperature increase (IIED, 2014).
} 
Pathways Project (DDPP) work on illustrative pathways for the transition to a low-carbon economy. In their scenarios, teams from developing countries such as India (Mathur et al., 2014), South Africa (Trollip et al., 2014) and Indonesia (Siagian et al., 2014) emphasize the need for poverty alleviation as the highest priority. This objective is translated in each of these national energy scenarios into a $100 \%$ access to modern energy in the next decades.

Given the service life of infrastructure and facilities, it is essential that all the resources devoted to alleviating poverty should include a dual carbon and climate constraint. In other words, just as the battle against climate change can only be stepped up if it makes allowance for the imperatives of development and alleviating poverty, so development strategies must integrate a decarbonized approach and adaptation to climate-change impacts. It is consequently legitimate that international climate negotiations should provide a concrete response, in particular on funding mechanisms, to enable and extend efforts to alleviate poverty, while integrating the climate constraint in the adaptation and mitigation branches.

This in turn prompts the need for mechanisms which would drive policies simultaneously targeting poverty alleviation, climate adaptation and/or mitigation. Our paper seeks to demonstrate the relevance of a Poverty-Adaptation-Mitigation Window (PAM-W) that would be implemented within the Green Climate Fund and presents its main features. In the first part of the paper we assess the way existing funding sources and climate funds have allowed for this dimension, and we highlight the limitations of these approaches. After describing the Green Climate Fund, the second part draws on the above appraisal to propose a specific funding window for poverty, adaptation and mitigation, in such a way as to target poverty alleviation while making allowance for the climate constraint.

\section{The limits of current climate funds in addressing poverty}

Fankhauser and Schmidt-Traub (2010) estimate that for Africa to achieve the Millennium Development Goals in a climate-resilient manner, it would need $40 \%$ more external funding 
than it would simply to achieve the original goals. This would mean about $\$ 100$ billion per year in 2010-20, compared to $\$ 72$ billion a year to attain the MDGs ${ }^{2}$.

Since they were launched the existing multilateral climate funds ${ }^{3}$ have collected $\$ 3$ billion for adaptation, a little over twice as much, $\$ 6.5$ billion, for mitigation excluding REDD ${ }^{4}$ (the Clean Technology Fund alone represents $\$ 4.6$ billion), and $\$ 4.6$ billion for REDD mechanisms (see Table 1).

Table 1: Main international climate funds

\begin{tabular}{|c|c|c|c|c|}
\hline Funds & \begin{tabular}{|l|} 
Disbursements \\
(M\$) up to \\
2013
\end{tabular} & Administered by & Focus & $\begin{array}{l}\text { Implemen } \\
\text { tation } \\
\text { date }\end{array}$ \\
\hline \multicolumn{5}{|c|}{ Main adaptation funds } \\
\hline Adaptation Fund & 406 & Adaptation Fund Board & Adaptation & 2009 \\
\hline $\begin{array}{l}\text { Adaptation for Smallholder } \\
\text { Agriculture Program }\end{array}$ & 300 & $\begin{array}{l}\text { The International Fund for Agricultural } \\
\text { Development (IFAD) }\end{array}$ & Adaptation & 2012 \\
\hline $\begin{array}{l}\text { Least Developed Countries } \\
\text { Fund }\end{array}$ & 903 & The Global Environment Facility (GEF) & Adaptation & 2002 \\
\hline $\begin{array}{l}\text { Special Climate Change } \\
\text { Fund }\end{array}$ & 336 & The Global Environment Facility (GEF) & Adaptation & 2002 \\
\hline $\begin{array}{l}\text { Pilot Program for Climate } \\
\text { Resilience }\end{array}$ & 973 & The World Bank & Adaptation & 2008 \\
\hline Total & 2919 & & & \\
\hline \multicolumn{5}{|c|}{ Main mitigation funds } \\
\hline Clean Technology Fund & 4599 & The World Bank & Mitigation & 2008 \\
\hline $\begin{array}{l}\text { Global Energy Efficiency } \\
\text { and Renewable Energy } \\
\text { Fund }\end{array}$ & 169 & The European Commission & Mitigation & 2008 \\
\hline $\begin{array}{l}\text { Scaling-Up Renewable } \\
\text { Energy Program for Low } \\
\text { Income Countries }\end{array}$ & 506 & The World Bank & Mitigation & 2009 \\
\hline $\begin{array}{l}\text { GEF Trust Fund - Climate } \\
\text { Change focal area (GEF 4) }\end{array}$ & 1083 & The Global Environment Facility (GEF) & $\begin{array}{l}\text { Adaptation, } \\
\text { Mitigation }\end{array}$ & 2006 \\
\hline
\end{tabular}

\footnotetext{
${ }^{2}$ The usual estimates of the cost of achieving the MDGs (UN Millennium project, 2005; Bourguignon et al, 2008; Ban et al, 2008; Jones et al, 2003) do not include the additional cost of adaptation and the need to cope with a hostile climate.

${ }^{3}$ In this part we disregard the Green Climate Fund, currently being operationalized and slated ultimately to become the main climate fund. It will be addressed in the second part.

${ }^{4}$ REDD stands for Reducing Emissions from Deforestation and Forest Degradation
} 


\begin{tabular}{|c|c|c|c|c|}
\hline $\begin{array}{l}\text { GEF Trust Fund - Climate } \\
\text { Change focal area (GEF 6) }\end{array}$ & 192 & The Global Environment Facility (GEF) & $\begin{array}{l}\text { Adaptation, } \\
\text { Mitigation }\end{array}$ & 2006 \\
\hline Total & 6543 & & & \\
\hline \multicolumn{5}{|c|}{ Main REDD+ funds } \\
\hline UN-REDD & 251 & & $\begin{array}{l}\text { Mitigation - } \\
\text { REDD }\end{array}$ & 2009 \\
\hline $\begin{array}{l}\text { Norway's International } \\
\text { Climate and Forest } \\
\text { Initiative }\end{array}$ & 1607 & UNDP & $\begin{array}{l}\text { Mitigation - } \\
\text { REDD }\end{array}$ & 2008 \\
\hline $\begin{array}{l}\text { Forest Investment Program } \\
\text { (FIP) }\end{array}$ & 599 & The World Bank & $\begin{array}{l}\text { Mitigation - } \\
\text { REDD }\end{array}$ & $\begin{array}{l}\text { The World } \\
\text { Bank }\end{array}$ \\
\hline $\begin{array}{l}\text { Forest Carbon Partnership } \\
\text { Facility - Readiness Fund } \\
\text { (FCPF-RF) }\end{array}$ & 355 & The World Bank & $\begin{array}{l}\text { Mitigation - } \\
\text { REDD }\end{array}$ & 2008 \\
\hline $\begin{array}{l}\text { Forest Carbon Partnership } \\
\text { Facility - Carbon Fund } \\
\text { (FCPF-CF) }\end{array}$ & 388 & The World Bank & $\begin{array}{l}\text { Mitigation - } \\
\text { REDD }\end{array}$ & 2008 \\
\hline $\begin{array}{l}\text { Congo Basin Forest Fund } \\
\text { (CBFF) }\end{array}$ & 186 & African Development Bank & & \\
\hline $\begin{array}{l}\text { Australia's International } \\
\text { Forest Carbon Initiative }\end{array}$ & 216 & & & \\
\hline Amazon Fund & 1033 & Brazilian Development Bank (BNDES) & & 2009 \\
\hline Total & 4637 & & & \\
\hline
\end{tabular}

Predictably these funds fall far short of what is needed to keep global warming below the $2^{\circ} \mathrm{C}$ limit and provide vulnerable countries with the capacity to adapt. Which is why, following the Copenhagen Accord, the industrialized countries set a target of raising $\$ 100$ billion a year up to 2020, in order to support mitigation and adaptation actions in developing countries.

Looking beyond these figures we need to examine more closely how combating poverty has so far been integrated into existing climate funds. 
1. How much goes to the poor in the share-out of existing funds?

\section{a) Adaptation}

There is no single methodology for the resource allocation of existing adaptation funds (Klein and Möhner, 2011).

Several vulnerability indicators have nevertheless been proposed in the literature to ensure that adaptation funding targets the countries most exposed to the impacts of climate change (Barr et al, 2010; Buys et al, 2009; Füssel, 2010; Wheeler, 2011). But the rankings of countries yielded by the various indicators are very divergent (Persson and Remling, 2014).

Nakhooda et al. (2014) use the global adaptation index GAIN ${ }^{5}$ to show that the countries receiving the most funding for adaptation ${ }^{6}$ are indeed among those most exposed to climate-change impacts. Meanwhile, Stadelmann et al. (2013), or Persson and Remling (2014) show that the Adaptation Fund has targeted a small number of countries with both a low degree of vulnerability and high per-capita income.

Some authors are wary of how well aggregate indicators reflect the specific needs of countries, given the diversity of adaptive needs (Klein and Persson, 2008). Some actions are designed to cope with the direct impacts of climate change, whereas others relate to reducing vulnerability arising out of poverty and its associated ills (informal housing, shanty towns, use of non-commercial energy sources, lack of sanitation, etc.). So it seems necessary to use indicators that are more sector-based, reflecting the reality on the ground more accurately (Füssel, 2010), or indeed mechanisms specific to each type of vulnerability (Hallegatte, 2011), in order to make combating poverty a strategic priority for adaptation.

\section{b) Mitigation}

Nakhooda et al. (2014) show that the bulk of funding for mitigation has gone to countries which either have a high level of greenhouse-gas emissions or are registering rapid growth in this respect. Ten countries received 74\% of funding: Mexico and Morocco each received more than $\$ 500$ million, followed by South Africa, India and Indonesia. The Clean Technology

\footnotetext{
${ }^{5}$ The Notre Dame Global Adaptation Index (GAIN) comprises a vulnerability index for water, food, health, housing, ecosystem and infrastructure regarding exposure to climate risks, and a readiness index describing the capacity of a country to make use of financial resources for adaptation. See http://index.gain.org

${ }^{6}$ By order of funding: Bangladesh, Niger, Mozambique, Zambia, Cambodia, Nepal, Tajikistan, Samoa, Bolivia and Yemen.
} 
Fund plays a predominant role here, accounting for about $70 \%$ of all mitigation funding. Little climate-change mitigation funding has gone to the least developed countries, with a total of \$203 million being allocated to mitigation (including REDD) in sub-Saharan Africa (Nakhooda et al, 2011). These conclusions are reminiscent of the Clean Development Mechanism's lopsided geographical distribution, with projects concentrated in China, India and Mexico (Dechezlepretre et al, 2008; Winkelman and Moore, 2011), whereas only 3\% of the emission-reduction credits were generated in Africa (Röttgers and Grote, 2014).

These observations reveal the climate-centred side of international negotiations and the resulting funding mechanisms. Mitigation-assessment indicators in flexibility mechanisms hinge on the tonnes of $\mathrm{CO}_{2}$ eq reduction generated. In project mechanisms the tonnes of $\mathrm{CO}_{2}$ eq reductions are calculated in relation to a baseline scenario (Gillenwater, 2012). This approach complicates funding of low-carbon projects by climate funds in the case of development and poverty-reduction projects with a very low level of energy services in the baseline scenario.

In the least developed countries, for example, the rate of electrification is low. If the current figure was taken as the baseline scenario, it would be difficult to find much scope for cutting emissions as electrification progresses, even if generating the additional electricity entails limited carbon emissions. It would of course be possible to adopt a methodology developed under the CDM to make allowance for suppressed demand. The baseline used in this case is the minimum service level for energy, even if it has not yet been reached (UNFCCC, 2014). But even here, the emissions abatement achieved by a low-carbon electrification project is likely to be very slight, when set against the baseline scenario.

So there is good cause to ask whether the 'tonnes of $\mathrm{CO}_{2}$ eq reduction' indicator is suitable for assessing 'low-carbon development' actions.

This review of existing climate funds suggests that to guarantee funding for adaptation and mitigation actions in the context of poverty, fresh thought is needed about the indicators used to select and assess projects and policies for funding. Otherwise the scarcity of available resources is likely to leave the poorest populations on the sidelines of climate funding. 
2. Phase out project-based approaches in favour of more ambitious strategies

In recent years a vast body of literature has questioned the merits of project-based approaches for funding climate actions.

The limitations of a project-based mechanism such as the CDM with regard to its structuring effects are all too apparent. Authors have consequently put the accent on sector-based approaches (Samaniego and Figueres, 2002) or even proposed funding to support the deployment of SD-PAMs (Winkler et al, 2002).

Firstly, having a large number of small projects entails high transaction costs (Ahonen and Hämekoski, 2005; Michaelowa et al, 2003 ; Michaelowa and Jotzo, 2005) which jeopardize the overall efficiency of funding. Africa is a particularly sensitive area in this respect, with the average adaptation project amounting to $\$ 4$ million, rising to $\$ 17$ million for mitigation. Out of all the 483 projects funded by one of the existing climate funds, only nine amounted to more than $\$ 50$ million (Afful-Koomson, 2014).

Secondly a host of small schemes will not trigger the paradigm shift required to put these countries on climate-change-resilient, low-carbon pathways. Regarding adaptation, the project-based approach seems better suited to funding actions addressing the direct impacts of climate change, which would not otherwise be carried out (building a dyke for example). In contrast, for adaptation needs related to development and poverty issues, adaptation strategies can be integrated into development strategies, making it more difficult to evaluate the additional cost that would determine the financial support in the case of a project-based approach.

\section{Make programmes attractive to private investors}

One essential issue is to redirect public and private investment to actions compatible with development pathways integrating climate-change constraints (Hourcade et al, 2009), or quite simply to attract private investors, currently deterred by inadequate institutional capacity or serious political instability. To this end, goals must be made more consistent and get solid backing at national level. Guivarch and Mathy (2012) have shown that in India institutional shortcomings and cross subsidies for electricity tariffs, set up in the name of the right of access to electricity, constitute a major hindrance to broadening access to power. In this context tariff reform, combined with a large scale energy-efficiency drive and support 
for renewable energies (by feed-in tariffs, for example), would substantially improve the financial situation of the energy sector, make various low-carbon investments profitable, and broaden access to energy. Support for rolling out such policies may make it easier to mobilize the private sector, at least in some countries and regions (Bhaghat, 2012). The task may be more difficult elsewhere. In Africa, private funding only accounted for $\$ 5$ million, out of the existing climate funds which raised a total of $\$ 3.5$ billion (allocated but not paid) between 2003 and 2013. To remedy this situation Afful-Koomson (2014) stresses the need to enhance the ability of African countries to set up funding bodies and business models which secure funding by private investors, with the guarantee of lower risks and adequate rates of return. Having said that, over and above the need to mobilize the private sector, it is also necessary to encourage co-funding drawing on official development assistance, public domestic funds and climate funds.

So, existing climate funds are ill suited to fostering the necessary synergies between poverty reduction, adaptation and mitigation. In the second part of this paper we propose setting up a poverty-adaptation-mitigation window as part of the Green Climate Fund. This would overcome the obstacles discussed above and contribute to building synergies.

\section{For the creation of a poverty-adaptation-mitigation funding window as part of the Green Climate Fund}

In the following we shall describe the modalities for making the as yet not fully defined Green Climate Fund operational, then show how a poverty-adaptation-mitigation funding window (PAM-W) could fit into this framework.

\section{Features of the Green Climate Fund}

The Green Climate Fund originated in the Copenhagen Accord in 2009. The following year the Cancun Conference endorsed its creation. The fund aims to promote a paradigm shift to low-carbon, climate-change-resilient development pathways. It is set to become the world's main climate fund (GCF, 2011, §32) and thus one of the prime channels for delivering the $\$ 100$ billion a year promised by the industrialized nations at Copenhagen. These funds would be allocated to developing countries, from 2020 onwards, for adaptation, emissions abatement (including REDD+), development, technology transfer, and capacity building. By 
the end of 2014 the fund had collected $\$ 14.4$ billion and it should be in a position to fund its first actions during the second half of 2015. Resources should be equally divided between adaptation and mitigation, but the timeframe governed by this rule has yet to be determined. A Private Sector Facility (PSF) has been set up to encourage private participation, but the facility's share in the GCF has not been settled ${ }^{7}$. Other thematic funding windows could be established in the future (GCF, 2014a). Achieving a balanced share-out, in geographical terms, is also a priority, with among others, the goal of not sidelining the least developed countries. This is a sensitive issue. At the sixth meeting of the GCF Board China and India opposed an initial proposal to place a 5\% cap on funds allocated to any one country. The question of setting a minimum funding rate dedicated to the least developed countries was also raised.

\section{a) Country ownership of actions and modalities of access}

To encourage countries to appropriate projects, the fund will only finance actions in countries which do not object to them (GCF, 2014b). The fund provides for direct access through national, sub-national or regional bodies in addition to international access through international funding agencies and to access through the PSF for local and private financial intermediaries (GCF, 2014c):

These two points - the no-objection procedure and direct access - are two key components for ensuring that developing countries keep control over actions and funding bodies do not dictate their own conditions or programmes, as may have happened in the past (Nakhooda et al, 2014). However direct access assumes that national bodies in each country are accredited, which is not currently the case, although their number has substantially increased in recent years, with for example the Bangladeshi Climate Change Resilience Fund, the Brazilian Amazon Fund or the Ethiopian Climate Resilient Green Economy Facility.

\section{b) Measuring performance}

A results-management framework has been developed, underpinned by performancemeasurement matrices, thanks to which the impact, effectiveness and efficiency of funding will be assessed. For mitigation the main impact metric is GHG emissions reduction (in $\left.\mathrm{tCO}_{2} \mathrm{eq}\right)$, which again raises the question of this indicator's relevance for assessing the

\footnotetext{
${ }^{7}$ The financial weight, or even the existence, of the Private Sector Facility is open to controversy, some developing countries seeing it as a way for industrialized countries to dodge their funding commitments.
} 
performance of some low-carbon development projects, as discussed above. As for adaptation, the number of beneficiaries is the main impact metric.

\section{c) Selecting actions}

Six selection criteria have been set, without any indication of their relative weights (GCF, 2014d): the impact potential relative to the sustainable development and climate objectives of the Fund; the paradigm shift potential toward low-carbon and climate-resilient pathways; the financing needs of the beneficiary country; the capacity of the beneficiary country to implement policies; the economic efficiency of the funds delivered; financial viability (for revenue-generating activities).

The indicators to be used for each of these criteria have yet to be decided. For mitigation, if the first criterion is assessed on the basis of emissions reductions (in $\mathrm{tCO}_{2}$ eq) compared with a baseline scenario, it will run into the problems discussed above with regard to low-carbon development projects in which a baseline scenario contains few GHG emissions. In the case of adaptation, if the indicator is the number of beneficiaries, that may be consistent with poverty-reduction goals. As for the third criterion, bearing in mind the first part of our paper, it would jeopardize the poorest countries to select an aggregate indicator, as it would give a poor reflection of real conditions in the country, in particular the degree of satisfaction of the basic needs of a large share of the population.

\section{Suggested features of the PAM-W}

The Green Climate Fund has not provided for a specific facility for simultaneously targeting the triple issue of poverty, adaptation and mitigation. The only features are scope for putting a X\% cap on the share of GCF resources allocated to any one country (e.g. 5\%) or indeed directing $\mathrm{X} \%$ of resources to the least developed countries. In the following we propose to create a special funding window, within the GCF, dedicated to the links between poverty, adaptation and mitigation (PAM-W), supplementing the funding windows for adaptation and mitigation.

\section{a) Building synergies between poverty-reduction, adaptation and mitigation}

The proposed mechanism aims to build synergies between poverty-reduction, adaptation and mitigation in such a way as to pool efforts and ensure that infrastructure and facilities developed under the mechanism are both climate-change resilient and contribute to low- 
carbon development. This will avoid the need to phase out facilities before the end of their service life because they made little or no allowance for all the adaptation and emissions constraints. Typical actions potentially concerned by such a mechanism would include building homes to reduce the number of people living in slums, and integrating bioclimatic building techniques, suited to changing climate conditions but also entailing low energy consumption and GHG emissions. Examples may be grouped in relation to basic needs as shown in table 2.

Table 2: Sectoral convergence between satisfaction of basic needs, adaptation and mitigation. Examples of possible criteria for setting priorities when allocating PAM-W resources.

\begin{tabular}{|c|c|c|c|c|c|}
\hline & $\begin{array}{l}\text { Poverty- } \\
\text { reduction goal }\end{array}$ & $\begin{array}{l}\text { GHG-reduction } \\
\text { goal }\end{array}$ & Adaptation goal & $\begin{array}{l}\text { Example of } \\
\text { action }\end{array}$ & $\begin{array}{l}\text { Eligibility and } \\
\text { allocation criteria }\end{array}$ \\
\hline 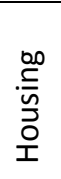 & $\begin{array}{l}\text { Reduce number } \\
\text { of people living in } \\
\text { slums }\end{array}$ & $\begin{array}{l}\text { Limit GHG } \\
\text { emissions from } \\
\text { new housing }\end{array}$ & $\begin{array}{l}\text { Reduce exposure } \\
\text { to extreme } \\
\text { events }\end{array}$ & $\begin{array}{l}\text { Promote } \\
\text { bioclimatic } \\
\text { building } \\
\text { techniques }\end{array}$ & $\begin{array}{l}\text { Weighting (Number of } \\
\text { people in country } \\
\text { living in slums, overall } \\
\text { population) }\end{array}$ \\
\hline $\begin{array}{l}\text { 믐 } \\
\text { 안 }\end{array}$ & $\begin{array}{l}\text { Reduce number } \\
\text { of people } \\
\text { suffering from } \\
\text { malnutrition }\end{array}$ & $\begin{array}{l}\text { Limit GHG } \\
\text { emissions from } \\
\text { agriculture }\end{array}$ & $\begin{array}{l}\text { Reduce } \\
\text { vulnerability of } \\
\text { agriculture to } \\
\text { climate change }\end{array}$ & $\begin{array}{l}\text { Improve } \\
\text { agricultural } \\
\text { efficiency from } \\
\text { farm to fork }\end{array}$ & $\begin{array}{l}\text { Weighting (Number of } \\
\text { people in country } \\
\text { suffering from } \\
\text { malnutrition, overall } \\
\text { population) }\end{array}$ \\
\hline 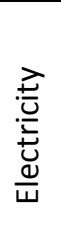 & $\begin{array}{l}\text { Reduce number } \\
\text { of people } \\
\text { without } \\
\text { electricity }\end{array}$ & $\begin{array}{l}\text { Limit GHG } \\
\text { emissions from } \\
\text { electricity } \\
\text { generation }\end{array}$ & $\begin{array}{l}\text { Contribute to } \\
\text { resilience of } \\
\text { electricity sector }\end{array}$ & $\begin{array}{l}\text { Develop } \\
\text { decarbonized } \\
\text { electricity } \\
\text { generation and } \\
\text { energy efficiency }\end{array}$ & $\begin{array}{l}\text { Weighting (Number of } \\
\text { people in country } \\
\text { without electricity, } \\
\text { overall population) }\end{array}$ \\
\hline$\underset{\substack{n \\
\tilde{n} \\
3}}{3}$ & $\begin{array}{l}\text { Reduce pollution, } \\
\text { increase rate of } \\
\text { waste processing }\end{array}$ & $\begin{array}{l}\text { Limit GHG } \\
\text { emissions from } \\
\text { waste }\end{array}$ & $\begin{array}{l}\text { Limit health } \\
\text { impacts of badly } \\
\text { managed waste } \\
\text { in the context of } \\
\text { climate change }\end{array}$ & $\begin{array}{l}\text { Waste-gas } \\
\text { capture facilities }\end{array}$ & $\begin{array}{l}\text { Weighting (Number of } \\
\text { people in country } \\
\text { exposed to severe } \\
\text { pollution, overall } \\
\text { population) }\end{array}$ \\
\hline 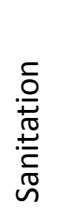 & $\begin{array}{l}\text { Reduce number } \\
\text { of people } \\
\text { without } \\
\text { sanitation }\end{array}$ & $\begin{array}{l}\text { Limit GHG } \\
\text { emissions from } \\
\text { effluents }\end{array}$ & $\begin{array}{l}\text { Limit exposure to } \\
\text { flooding and/or } \\
\text { epidemics } \\
\text { (extreme events) }\end{array}$ & $\begin{array}{l}\text { Develop efficient } \\
\text { or improved } \\
\text { sewerage } \\
\text { networks }\end{array}$ & $\begin{array}{l}\text { Weighting (Number of } \\
\text { people in country } \\
\text { without sanitation, } \\
\text { overall population) }\end{array}$ \\
\hline
\end{tabular}




\begin{tabular}{|c|c|c|c|c|c|}
\hline $\begin{array}{l}\frac{t}{0} \\
\frac{2}{n} \\
\frac{1}{\pi} \\
\stackrel{1}{1}\end{array}$ & $\begin{array}{l}\text { Broaden access } \\
\text { to mobility and } \\
\text { improve public } \\
\text { health in cities }\end{array}$ & $\begin{array}{l}\text { Limit GHG } \\
\text { emissions from } \\
\text { vehicles }\end{array}$ & $\begin{array}{l}\text { Build climate- } \\
\text { resilient } \\
\text { infrastructure }\end{array}$ & $\begin{array}{l}\text { Public transport } \\
\text { networks, soft } \\
\text { mobility modes }\end{array}$ & $\begin{array}{l}\text { Weighting (Number of } \\
\text { people in country } \\
\text { without access to } \\
\text { enhanced mobility, } \\
\text { overall population) }\end{array}$ \\
\hline $\begin{array}{l}\frac{F}{\frac{ \pm}{\pi}} \\
\frac{\mathbb{\Psi}}{I}\end{array}$ & $\begin{array}{l}\text { Improve public } \\
\text { health and } \\
\text { broaden access } \\
\text { to treatment }\end{array}$ & - & $\begin{array}{l}\text { Limit exposure to } \\
\text { epidemics and } \\
\text { extreme events }\end{array}$ & $\begin{array}{l}\text { Increase rate of } \\
\text { healthcare } \\
\text { coverage }\end{array}$ & $\begin{array}{l}\text { Weighting (Number of } \\
\text { people in country } \\
\text { without access to } \\
\text { healthcare, overall } \\
\text { population) }\end{array}$ \\
\hline
\end{tabular}

\section{b) Criteria reflecting satisfaction of basic needs for allocation and assessment}

Under the PAM-W, allocation would target countries which fall far short of satisfying basic needs. To this end we propose to select sector-based, national criteria, specific to each need. This responds in part to the objections raised by Füssel (2010), and Klein and Möhner (2011) regarding the limitations inherent in defining a single aggregate vulnerability indicator. Several separate indicators may be more suitable, making it possible to define a set of diverse situations more accurately.

In order to avoid allocating a large share of funding to a few highly populated countries (for example, a quarter of the population of India [400 million people] have no access to electricity; at the same time some countries in sub-Saharan Africa have only very limited access to modern energy sources, but have a smaller overall population) the fund allocation criterion should weight the degree of failure to satisfy a basic need for each sector and the overall population.

The goal of the PAM-W, and consequently of its ex post assessment criterion, is to maximize the number of people for whom a basic need will be satisfied, subject to the conditions of PAM-W eligibility, in other words making allowance for adaptation and/or low-carbon development concerns.

Resorting to this sort of criteria answers the concern of developing countries that priority should be given to combating poverty. The other merit of these criteria is that they are complementary (Stadelmann et al, 2013) for assessing the equity with which resources are allocated but also the efficiency of an action, in the sense that it effectively reduces the symptoms of poverty. 


\section{c) Levels of aid}

The levels of aid provided by funding will be determined by a sector-based approach to each type of basic need, in order to establish international benchmarks. The first step would be to determine the cost of satisfying these basic needs for each sector: per capita cost of access to electricity, to improved sanitation, to waste management, and so on. The Camdessus report (2003) estimated that providing 19 million people living in rural areas of Africa with access to drinking water and a sewage network would cost $\$ 1.4$ billion a year from 2003 to 2010. If this estimate was selected for all the countries, then for each additional person gaining access to these services, a country would receive $\$ 74$ wholly or in part. Similarly, according to the International Energy Agency (2011, p.3), "to provide universal modern energy access by 2030 annual average investment needs to average $\$ 48$ billion per year, more than five times the level of 2009". The same report asserts that electrification alone would require an investment of between $\$ 550$ and $\$ 740$ per person, depending on the type of access (on-grid, mini-grid or off-grid). Returns on experience from the existing climate funds and the Clean Development Mechanism also enable us to estimate the surplus cost entailed by carbon-free technology.

The share of this cost covered by the PAM-W would depend on several factors:

i) The overall envelope allocated to the funding window;

ii) For projects including mitigation, the level of aid should be sufficient, over and above other funding and aid, to take charge of any excess cost arising out of the use of carbon-free or low-carbon technology ;

iii) For projects including adaptation, the PAM-W would cover all or part of funding, depending on whether climate change is the main reason for the action, or one among several;

iv) The aid ratios for the adaptation branch and the mitigation branch will be added up.

By adopting this approach the mitigation branch would no longer need to debate baseline scenarios and would limit transaction costs. The negotiations to set the ratios are nevertheless likely to be difficult. They should be carried out in consultation with developing 
countries and will entail adapting all the ratios to reflect the specific conditions in each country.

\section{d) Payments based on results}

Scope for the PAM-W being partly supported by results-based payments should be investigated, in particular with a view to direct access to funding by a national entity ${ }^{8}$. The aim of this approach is to make payment of all or part of funding conditional on achieving targets. For this purpose a framework for assessing and monitoring results will need to be deployed, underpinning an array of appropriate performance indicators (GCF, 2011, §58). This type of aid has already been envisaged for REDD activities under the GCF. It has already been experimented by the World Bank, but on a limited project scale, and by the Energy+ partnership. Similar proposals have been made for the GCF (Müller, 2013; Michaelowa and Hoch, 2013). Instruments of this sort are an additional incentive for achieving goals (Eichler and Levine, 2009; Mumssen et al., 2010).

As in the Green Climate Fund modalities aiming at enhancing ownership of actions, the PAMW would have no mandate to discuss a country's specific strategy for carrying out actions and helping to improve the standard of living of its population, this being a matter of national sovereignty. Only results would be observed. The revenue contributed by the PAM$\mathrm{W}$ and covered by an ex post guarantee could be used to leverage project funding.

\section{e) Modalities of support and country ownership of actions}

The PAM-W will be able to fund, without distinction, a subsidy on the total value of infrastructure investments, a subsidy on usage costs (funding of a feed-in tariff scheme such as the one proposed by Michaelowa and Hoch (2013), for example) or other types of aid. Similarly countries must be free to decide how actions should be funded: out of their own assets, through private domestic or foreign investment, or from development aid. In view of the huge amount of funding required to cope with the challenges of adaptation and mitigation in developing countries, and the likelihood of only limited financial resources being available under the GCF, the modalities of support for these countries must limit as far as possible any windfall effects. As investigated by Khan and Schinn (2013), or Michaelowa and Hoch (2013), specific financial-support modalities will be applied as a function of each

\footnotetext{
${ }^{8}$ The GCF mentions the option of results-based funding (GCF, 2011, §59; GCF, 2014e).
} 
country's national income (based on the typology used by the World Bank) (see Table 3). Additional conditions may be set to demonstrate that a country is seriously committed to the paradigm shift which the GCF must entail, and/or regarding the need for co-funding, in particular from private sources, for lower and upper middle-income countries. For lowincome countries, co-funding by public development aid, or conventional public or private funding will be needed. Moreover setting such conditions will favour country ownership of actions, as well as increase scope for direct access to PAM-W funding.

Table 3: modalities of PAM-W support depending on a country's category

\begin{tabular}{|l|l|l|l|l|}
\hline & $\begin{array}{l}\text { Small-island } \\
\text { states }\end{array}$ & $\begin{array}{l}\text { Low-income } \\
\text { countries }\end{array}$ & $\begin{array}{l}\text { Lower middle- } \\
\text { income } \\
\text { countries }\end{array}$ & $\begin{array}{l}\text { Upper middle- } \\
\text { income } \\
\text { countries }\end{array}$ \\
\hline Mitigation & Donations & Donations & $\begin{array}{l}\text { Concessional } \\
\text { loans \& } \\
\text { donations (30\%) }\end{array}$ & $\begin{array}{l}\text { Concessional } \\
\text { loans }\end{array}$ \\
\hline Adaptation & Donations & Donations & Donations & $\begin{array}{l}\text { Concessional } \\
\text { loans }\end{array}$ \\
\hline
\end{tabular}

\section{Conclusion}

Existing climate funds have difficulty providing a suitable response to the specific demands of the poorest populations with regard to climate-change adaptation and mitigation. To fill the gap this article proposes setting up a specific funding window for poverty, adaptation and mitigation as part of the Green Climate Fund.

One of the key features of the PAM-W is that it bases the criteria for selecting and assessing actions to be funded on the satisfaction of sectoral basic needs and their change after completion of the actions. By setting a level of aid proportionate to the number of beneficiaries, the mechanism avoids the need to discuss baseline scenarios, thus limiting transaction costs. The talks to decide the level of aid and funding modalities will certainly be very difficult. Defining "access to basic needs" and monitoring results may also raise methodological issues, but it is important that they do not dramatically raise transaction costs. An assessment of the overall amount of financial needs for the PAM-W to be consistent with SDGs is also needed. Additional research on these topics will be driven. 
The principle of the right to development is central to this proposition, in that it targets the satisfaction of populations' basic needs. It defines a country continuum, given that there are poor people everywhere; all developing countries are therefore eligible with a mechanism of this sort, subject to funding modalities dependent on their income level.

Lastly the PAM-W responds, at least in part, to the demands of developing countries, for whom eradicating poverty is the prime objective. As such it could contribute to overcoming some of the obstacles holding up talks in international climate negotiations. In the run-up to the next round of negotiations at COP 21 in Paris, the PAM-W could spur developing countries to integrate more ambitious emissions limitations pledges into their Intended Nationally Determined Contributions. This could in turn entice industrialized countries to act similarly. In the end, it could pave the way to an ambitious climate agreement. 


\section{References}

Afful-Koomson T. (2014): The Green Climate Fund in Africa: what should be different? Climate and Development, DOI: 10.1080/ 17565529.2014.951015.

Ahonen, H-M., and K., Hämekoski. (2005). Transaction Costs under the Finish CDM/JI Programme. University of Helsinki. Discussion Paper. Helsinki.

Ban, K. M., A. Al-Madani, J.M. Barroso, A. Gurria, D. Kaberuka, D. Strauss-Kahn, J.Ping, R. Zoellick (2008). Achieving the MDGs. Recommendations of the MDG Africa Steering Group. New York. [Retrieved from http://www.mdgafrica.org/recommendations.html]

Barr, R., Fankhauser, S., Hamilton, K. (2010). Adaptation investments: A resource allocation framework. Mitigation and Adaptation Strategies for Global Change, 15, 843-858. DOI 10.1007/s11027-010-9242-1.

Beg, N., Corfee Morlot, J., Davidson, O., Afrane-Okesse, Y., Tyani, L., Denton, F., Sokona, Y., Thomas, J.P., Lèbre La Rovere, E., Parikh, J.K., Parikh, K., Rahman, A. A.(2002). Linkages between climate change and sustainable development. Climate Policy, 2, 129-144

Bhagat, C., Honda, K., Pandit, V., Pinshaw, G., Roy, B., Yoo, Y. (2012). Private equity's new Asian strength. [Retrieved from http://www.mckinsey.com/insights/asiapacific/private_equitys_new_asian_strength]

Bourguignon, F. , C. Diaz-Bonilla and H. Lofgren (2008). Aid, Service Delivery, and the Millennium Development Goals in an Economy-Wide Framework. World Bank Policy Research Working Paper No. 4683. Washington: DC.

Bradley, R., Baumert,K., (Ed.) in collaboration with Dubash, N., Moreira, J.R., Mwakasonda, S., Wei-Shiuen Ng, Horta Nogueira, L. A., Parente, V., Pershing, J., Schipper, L., Winkler, H. (2005). Growing in the greenhouse ; protecting the climate by putting development first. World Resources Institute (WRI) Report.

Buys, P., Deichmann, U., Meisner, C., Ton That, T., Wheeler, D. (2009). Country stakes in climate change negotiations: Two dimensions of vulnerability. Climate Policy, 9, 288-305.

Camdessus, M. (2003). Report of the World Panel on Financing Water Infrastructure, Financing Water for All, World Water Council, Written by J. Winpenny, 64 pp.

Clapp, C., Briner, G., Karousakis, K. (2011). Low-emission development strategies (LEDS) : technical, institutional and policy lessons. OECD and IEA, COM/ENV/EPOC/IEA/SLT(2010)2.

Dechezleprêtre, A., Glachant, M., Ménière, Y. (2008) Technology transfer by CDM projects: A comparison of Brazil, China, India and Mexico. Energy Policy, 37(2), 703-711.

Eichler, R., Levine, R. (2009). Performance Incentives for Global Health: Potential and Pitfalls. Washington DC, Center for Global Development. 
Fankhauser S., Schmidt-Traub G., (2010). From adaptation to climate-resilient development: the costs of climate-proofing the Millennium Development Goals in Africa. Policy paper. February 2010. Centre for Climate Change Economics and Policy Grantham Research Institute on Climate Change and the Environment.

Füssel, H.-M. (2010). How inequitable is the global distribution of responsibility, capability, and vulnerability to climate change: A comprehensive indicator-based assessment. Global Environmental Change, 20, 597-611.

Gertler, P., Shelef, O., Wolfram, C., Fuchs A.( 2011). Poverty, Growth, and the Demand for Energy, Working paper 224, Energy Institute at Haas

Gillenwater, M. (2012). What is additionality? Part 1: A long-standing problem. The Greenhouse Gas Management Institute. Discussion Paper Number 001 (Version 03)

Green Climate Fund (2011). Governing instrument for the Green Climate Fund, Durban

Green Climate Fund (2014a) Initial Modalities for the Operation of the Fund's Mitigation and Adaptation Windows and its Private Sector Facility. GCF B.07/08, Songdo.

Green Climate Fund (2014b) Country Ownership. GCF/B.06/07, Songdo.

Green Climate Fund (2014c) Additional Modalities That Further Enhance Direct Access, Including Through Funding Entities. GCF/B.08/09, Songdo.

Green Climate Fund (2014d) Initial Proposal Approval Process. GCF/B.07/06, Songdo.

Green Climate Fund (2014e) Business model framework: financial instruments. GCF/B.04/06, Songdo.

Guivarch C., Mathy S. (2012). Energy decoupling in a second best world. A case study in India, Climatic Change. July 2012, 113(2), 339-356.

Hallegatte, S. (2011). A Macro Output-Based Approach to Climate Change Adaptation Funding in Developing Countries, unpublished.

Hallegatte,S., Bangalore, M., Bonzanigo, L., Fay, M., Narloch, U., Rozenberg, J., Vogt-Schilb, A. (2014). Climate Change and Poverty; An Analytical Framework. Policy Research Working Paper 7126, W orld B ank Group.

Halsnæs, K., Garg, A. (2006). Sustainable Development, Energy and Climate:

Exploring Synergies and Tradeoffs Methodological Issues and Case Studies from Brazil, China, India, South Africa, Bangladesh and Senegal. UNEP Ris $\varnothing$ Centre, 72 p.

Hourcade J.C. Shukla P.R., Mathy S. (2009). Untying the Climate - Development Gordian Knot : Economic options in a politically constrained world. In R. Guesnerie and H. Tulkens (Eds.) The Design of Climate Policy, pp.75-99. MIT press.

International Energy Agency (IEA) (2011). Energy for all, financing access for the poor. 
International Energy Agency (IEA) (2014). World Energy Outlook Electricity Database.

International Institute for Environment and Development (IIED) (2014). Understanding key positions of the Least Developed Countries in climate change negotiations. Briefing, September, $4 p$.

Intergovernmental Panel on Climate Change (IPCC) (2007a). Contribution of Working Group II to the Fourth Assessment Report of the Intergovernmental Panel on Climate Change. M.L. Parry, O.F. Canziani, J.P. Palutikof, P.J. van der Linden and C.E. Hanson (Eds) . Cambridge University Press, Cambridge, United Kingdom and New York, NY, USA.

Intergovernmental Panel on Climate Change (IPCC) (2007b). Contribution of Working Group III to the Fourth Assessment Report of the Intergovernmental Panel on Climate Change. B. Metz, O.R. Davidson, P.R. Bosch, R. Dave, L.A. Meyer (Eds). Cambridge University Press, Cambridge, United Kingdom and New York, NY, USA.

Intergovernmental Panel on Climate Change (IPCC) (2014). Climate Change 2014: Synthesis Report. Contribution of Working Groups I, II and III to the Fifth Assessment Report of the Intergovernmental Panel on Climate Change [Core Writing Team, R.K. Pachauri and L.A. Meyer (eds.)]. IPCC, Geneva, Switzerland, 151 pp.

Jones, G., R. Steketee, R. Black, Z. Bhutta, S. Morris and the Bellagio Child Survival Study (2003). “How Many Child Deaths Can We Prevent This Year?" in: Lancet 362(9377): 65-71.

Kasa, S., Gullberg, A., Heggelund, G. (2008).The Group of 77 in the international climate negotiations: recent developments and future directions International. Environmental Agreements: Politics, Law and Economics, 8 (2), 113-127.

Khan F.I., Schinn D.S. (2013) Triple transformation. Nature Climate Change, 3, 692-694.

Klein, R. J., Möhner, A. (2011). The political dimension of vulnerability to the adverse effects of climate change. IDS Bulletin, 42(3), 15-22.

Klein, R. J., Persson, $A^{\circ}$. (2008). Financing adaptation to climate change: Issues and priorities (ECP Report No. 8, October). Brussels: The Centre for European Policy Studies.

Mathur R., Srivastava L., Kumar A., Awasthy A.,Mohan I. (2014). India country chapter. In E. Guerin (Ed.). Pathways to deep decarbonization: Interim 2014 report. Technical report, IDDRI and SDSN, $16 \mathrm{p}$.

Michaelowa A., Hoch S. (2013) FIT for Renewables? Design options for the Green Climate Fund to support renewable energy feed-in tariffs in developing countries. World Future Council.

Michaelowa A., Jotzo. F. (2005). Transaction Costs, Institutional Rigidities and the Size of the Clean Development Mechanism. Energy Policy 33: 511 - 523.

Michaelowa, A., Stronzik M., Eckermann F., Hunt A. (2003) Transaction Costs of the Kyoto Mechanisms. Climate Policy 3: 261-278. 
Müller, B. (2013): A Delhi Vision for the Green Climate Fund Business Model Framework Some Thoughts on Access and Disbursement, Oxford Energy and Environment Brief, February 2013, Oxford

Mumssen, Y., Johannes, L, Kumar, G. (2010). Output-Based Aid: Lessons Learned and Best Practice. Washington D.C., The World Bank.

Röttgers D., Grote U. (2014) Africa and the Clean Development Mechanism: What Determines Project Investments? World Development, 62, October, pp. 201-212.

Nakhooda S., Caravani A., Bird N., Schalatek L. (2011). Climate Finance in Sub-Saharan Africa. Climate Finance Policy Brief, 8p.

Nakhooda S., Norman M., Barnard S., Watson C., Greenhill R., Caravani A., Canales Trujillo N., Banton G. (2014) (2014) Climate finance: is it making a difference? A review of the effectiveness of multilateral climate funds, December, Overseas development Institute, London, 87p.

Persson, A., \& Remling, E. (2014). Equity and efficiency in adaptation finance: initial experiences of the Adaptation Fund. Climate Policy, 14(4), 488-506.

Rajamani, L. (2007). India's Negotiating Position on Climate Change: Legitimate but not Sagacious. Centre for Policy Research (CPR) Issue Brief, 4 p.

Röttgers, D., Grote, U. (2014). Africa and the Clean Development Mechanism: What determines project investments? World Development, 62,201-212.

Samaniego, J., Figueres, C. (2002). A Sector-Based Clean Development Mechanism. In K. Baumert, O. Blanchard O., S. Llosa \& J. Perkaus (Eds.), Building on the Kyoto Protocol: Options for Protecting the Climate. World Resources Institute.

Shepherd, A., Mitchell, T., Lewis, K., Lenhardt, A., Jones, L., Scott, L. and Muir-Woods, R. (2013) The geography of poverty, disasters and climate extremes in 2030. London: Overseas Development Institute.

Siagian UWR., Gumilang Dewi R., Hendrawan I., Boer R., Gintings G.E. (2014). Indonesia country chapter. In E. Guerin (Ed.). Pathways to deep decarbonization: Interim 2014 report. Technical report, IDDRI and SDSN, 2014, 12 p.

Skoufias E., Rabassa M., Olivieri S., Brahmbatt (2011). The poverty impacts of climate change. Economic Premise, $n^{\circ} 51$, Mars. The World bank

Stadelmann, M., Persson A., Ratajczak-Juszko, I., Michaelowa, A. (2013). Equity and costeffectiveness of multilateral adaptation finance: Are they friends or foes? International Environmental Agreements: Politics, Law and Economics, 1, 1-20.

Trollip H,. Winkler H., Merven B. (2014). South Africa country chapter. In E. Guerin (Ed.). Pathways to deep decarbonization: Interim 2014 report. Technical report, IDDRI and SDSN, 2014, 14 p. 
United Nations (UN) Millennium Project. (2005). Investing in Development: A Practical Plan to Achieve the Millennium Development Goals.

United Nations Environment Programme (UNEP), (2014). The Emissions Gap Report 2014. A UNEP synthesis report.

United Nations Development Programme (UNDP), (2014). The Millennium Development Goals Report 2014.

United Nations Economic Commission for Africa (UNECA), African Union, African Development Bank and United Nations Development Programme (UNDP) (2014). MDG Report 2014: Assessing Progress in Africa toward the Millennium Development Goals.

United Nations Framework Convention on Climate Change (UNFCCC), (2009). Report of the Conference of the Parties on its fifteenth session, held in Copenhagen from 7 to 19 December 2009. Addendum. Part Two: Action taken by the Conference of the Parties at its fifteenth session. FCCC/CP/2009/11/Add.1.

United Nations Framework Convention on Climate Change (UNFCCC), (2010). Report of the Conference of the Parties serving as the meeting of the Parties to the Kyoto Protocol on its sixth session, held in Cancun from 29 November to 10 December 2010. Addendum. Part two: Action taken by the Conference of the Parties serving as the meeting of the Parties to the Kyoto Protocol at its sixth session. FCCC/CP/2010/7/Add.1

United Nations Framework Convention on Climate Change (UNFCCC), (2013). Report of the Conference of the Parties on its nineteenth session, held in Warsaw from 11 to 23 November 2013. Addendum. Part two: Action taken by the Conference of the Parties at its nineteenth session. $\mathrm{FCCC} / \mathrm{CP} / 2013 / 10 /$ Add.1

United Nations Framework Convention on Climate Change (UNFCCC), (2014). CDM methodology booklet. $6^{\text {th }}$ edition, November, $260 \mathrm{p}$.

United Nations (UN)-Habitat for a better urban future, (2013). Streets as Public Spaces and Drivers of Urban Prosperity.

UN Millennium Project (2005). Investing in Development: A Practical Plan to Achieve the Millennium Development Goals. London: Earthscan

Wheeler, D. (2011) Quantifying vulnerability to climate change: implications for adaptation assistance. Centre for Global Development Working Paper 240, January 2011. Centre for Global Development, Washington DC.

Winkelman A.G., Moore M.R., (2011). Explaining the differential distribution of Clean development Mechanism projects across host countries. Energy Policy, vol. 39, 3, p. 11321143.

Winkler, H., Spalding-Fecher, R., Mwakasonda, S., Davidson, O. (2002). Sustainable Development Policies and Measures: Starting From Development to Tackle Climate Change. 
In K. Baumert, O. Blanchard O., S. Llosa \& J. Perkaus (Eds.), Building on the Kyoto Protocol: Options for Protecting the Climate. World Resources Institute.

Wolfram, C., Shelef, O., Gertler, P. (2012). How Will Energy Demand Develop in the Developing World?, Journal of Economic Perspectives, 26, 1, 119-138. 